\title{
A MARINE RESERVOIR CORRECTION DATABASE AND ON-LINE INTERFACE
}

\author{
P J Reimer ${ }^{1} \bullet$ R W Reimer \\ School of Archaeology and Palaeoecology, Queen's University of Belfast, Belfast BT7 INN, Northern Ireland
}

\begin{abstract}
Calibration is essential for interpretation of radiocarbon dates, especially when the ${ }^{14} \mathrm{C}$ dates are compared to historical or climatic records with a different chronological basis. ${ }^{14} \mathrm{C}$ ages of samples from the marine environment, such as shells or fish bones, or samples with a marine component, such as human bone in coastal regions, require an additional consideration because of the reservoir age of the ocean. While the pre-industrial global mean reservoir correction, $\mathrm{R}(\mathrm{t})$, is about 400 years, local variations $(\Delta \mathrm{R})$ can be several hundred years or more. $\Delta \mathrm{R}$ compilations on a global scale have been undertaken previously (Stuiver et al. 1986; Stuiver and Braziunas 1993), but have not been updated recently. Here we describe an on-line reservoir correction database accessed via mapping software. Rather than publishing a static $\Delta \mathrm{R}$ compilation, new data will be incorporated when it becomes available. The on-line marine reservoir correction database can be accessed at the website http://www.calib.org/.
\end{abstract}

\section{INTRODUCTION}

Samples formed in the ocean mixed layer are generally several hundred years older than their atmospheric counterparts after proper correction for isotopic fractionation (Stuiver and Polach 1977). In order to calibrate a radiocarbon age for a marine sample one has either to 1) apply a correction for the marine reservoir age, $\mathrm{R}(\mathrm{t})$, to the conventional ${ }^{14} \mathrm{C}$ age of the sample and then calibrate using an atmospheric calibration curve; or 2) apply a correction for the regional variation from the marine reservoir age, $\Delta \mathrm{R}$, and calibrate using a marine calibration curve as first proposed by Stuiver et al. (1986). The latter method is generally preferred because atmospheric ${ }^{14} \mathrm{C}$ changes are attenuated in the ocean, which results in fewer "wiggles" in the calibration curve.

As a first approximation, $\Delta \mathrm{R}$ is assumed to be a constant for a given region and is calculated from the difference in ${ }^{14} \mathrm{C}$ years of known age marine samples and the marine model age for that calendar age. However, in some regions, ocean circulation patterns may have altered on both long term and short term time-scales (Austin et al. 1995; Druffel 1997). Long-term changes in $\Delta \mathrm{R}$ values can be obtained from the comparison of contemporaneous marine and terrestrial samples (Monges Soares 1993; Ingram and Southon 1996) or by obtaining a terrestrial age for marine samples by varve counts or tephra ages, for instance (Hughen et al. 1998; Sikes et al. 2000). The database described here currently incorporates only known age marine samples and the $\Delta \mathrm{R}$ values for each region are assumed to be constant. The addition of time-dependent data is planned.

Because the 1998 marine calibration curve back to $8800 \mathrm{cal} \mathrm{BP}$ is based on a marine model, changes in the atmospheric calibration data have resulted in changes in the marine calibration curve (Stuiver et al. 1998). Although the changes in the marine calibration curve are relatively small compared to the error in most ${ }^{14} \mathrm{C}$ measurements, $\Delta \mathrm{R}$ values have been recalculated to reflect these changes.

\section{METHODS}

${ }^{14} \mathrm{C}$ ages of known age, pre-nuclear marine samples from numerous publications were used to recalculate $\Delta \mathrm{R}$ values from the difference in the ${ }^{14} \mathrm{C}$ age and the 1998 marine calibration dataset (Marine98). In cases where the ${ }^{14} \mathrm{C}$ measurements were originally reported as $\delta^{14} \mathrm{C}, \Delta^{14} \mathrm{C}$, or pMC values, we recalculated the conventional ${ }^{14} \mathrm{C}$ age, correcting for isotopic fractionation if that had not been done previously. The uncertainty in $\Delta \mathrm{R}$ includes the standard error in the calibration dataset.

${ }^{1}$ Corrresponding author. Email: pjreimer@calib.org.

(C) 2001 by the Arizona Board of Regents on behalf of the University of Arizona

RADIOCARBON, Vol 43, Nr 2A, 2001, p 461-463

Proceedings of the 17 th International ${ }^{14} \mathrm{C}$ Conference, edited by I Carmi and E Boaretto 
Samples from depths greater than $75 \mathrm{~m}$ were not included in the database, because the marine model ages in the marine calibration dataset are only valid for the mixed layer.

Regional means were calculated for samples grouped either by the original authors, by previous compilers, or from our best guess at regional ocean circulation patterns. The uncertainty in $\Delta \mathrm{R}$ was taken as the maximum of the standard deviation, based on the reported error in the conventional sample ${ }^{14} \mathrm{C}$ ages, and the scatter sigma, which is the square root of the variance divided by the number of samples. Samples with collection dates after AD 1955 were not included in the regional mean, because coral and shell ${ }^{14} \mathrm{C}$ levels from most sites exhibit an increase shortly after this time due to nuclear bomb testing (Druffel and Linick 1978; Druffel 1981; Peck and Brey 1996; Druffel and Griffin 1999). Except in a few extreme cases, no other samples were excluded from the regional mean unless the date of death was uncertain and $\Delta \mathrm{R}$ was significantly larger than the mean. This was done to exclude those samples that may not have been collected within a short time of the death date, but not those that may reflect a real variance in $\Delta \mathrm{R}$.

Regional means are not given for samples from fjords due to the large natural variability in such data (Heier-Nielsen et al. 1995).

$\Delta \mathrm{R}$ values may differ for marine mollusks depending on the species, habitat, and/or substrate (Dye 1994; Forman and Polyak 1997; Hogg et al. 1998). No attempt has been made to separate results by species or substrate except where the original authors did so. In those cases, separate regional averages are given for deposit feeders, which may incorporate old carbon from sediments, and for gastropods living on limestone substrates.

The on-line interface to the database utilizes GMT mapping software (Wessel and Smith 1998). The user clicks on the region of interest on the world map and a regional map showing sample sites is displayed along with links to individual records and the regional mean. The on-line marine reservoir correction database can be accessed at http://www.calib.org/.

\section{DISCUSSION}

The marine reservoir correction database is intended for use with radiocarbon calibration programs such as CALIB (Stuiver and Reimer 1993) or OxCal (Bronk Ramsey 1995) and the 1998 marine calibration dataset. Regional mean $\Delta \mathrm{R}$ values are provided but it is left up to the user to decide which values are representative of their sample site. Reservoir corrections for lakes, bogs, and estuaries must be considered on an individual basis (cf. Olsson 1996; Lanting and van der Plicht 1998) and are not included at present.

The 1986 reservoir correction compilation of Stuiver and Braziunas included just over 100 preindustrial $\Delta \mathrm{R}$ values for 25 regions. A handful of references were added in 1993 (Stuiver and Braziunas 1993). At present, our on-line database contains over $450 \Delta \mathrm{R}$ measurements for 65 regions. The geographic coverage is biased towards North America and Europe, with Australia, New Zealand, and the South Pacific islands also having reasonable coverage. Little or no reservoir correction data exists for most of Africa, the Far East, Southeast Asia, and the east coast of South America, although new results for the Northwest Pacific, the Sea of Japan, and the northern Indian Ocean are now available (Dutta et al., 2001; Hideshima et al., 2001; Kuzmin et al., 2001). Many excellent shell collections are held in museums around the world and provide the potential for overcoming the difficulties associated with shell-derived dates. Yoneda et al. (2000) have demonstrated the need to select museum specimens carefully to ensure that the samples were collected live. The species, habitat, and the substrate of the collection site should also be considered as differences in $\Delta \mathrm{R}$ may result 
from a component of old carbon in the shell (Dye 1994; Forman and Polyak 1997; Hogg et al. 1998). Despite these necessary considerations, it is hoped that researchers will undertake to fill the gaps in the record.

\section{ACKNOWLEDGMENTS}

We would like to thank those researchers who have provided data or supplementary information for this database. Development of the on-line database was funded by the Institute for Aegean Prehistory.

\section{REFERENCES}

Austin WEN, Bard E, Hunt JB, Kroon D, Peacock JD. 1995. The ${ }^{14} \mathrm{C}$ age of the Icelandic Vedde Ash: implications for Younger Dryas marine reservoir age corrections. Radiocarbon 37(1):53-62.

Bronk Ramsey C. 1995. Radiocarbon calibration and analysis of stratigraphy: the OxCal program. Radiocarbon 37(2):425-30.

Druffel EM. 1981. Radiocarbon in annual coral rings from the eastern tropical Pacific Ocean. Geophysical Research Letters 8:59-62.

Druffel EM. 1997. Pulses of rapid ventilation in the North Atlantic surface ocean during the past century. Science 275:1454-7.

Druffel EM, Linick TW. 1978. Radiocarbon in annual coral rings of Florida. Geophysical Research Letters 5:913-6.

Druffel ERM, Griffin S. 1999. Variability of surface ocean radiocarbon and stable isotopes in the southwestern Pacific. Journal of Geophysical Research 104(C10):23,607-13.

Dutta K, Bhushan R, Somayajulu BLK. 2001. $\Delta$ R correction values for the Northern Indian Ocean. Radiocarbon. This issue.

Dye T. 1994. Apparent ages of marine shells: implications for archaeological dating in Hawai 'i. Radiocarbon 36(1):51-7.

Forman SL, Polyak L. 1997. Radiocarbon content of prebomb marine mollusks and variations in the ${ }^{14} \mathrm{C}$ reservoir age for coastal areas of the Barents and Kara seas, Russia. Geophysical Research Letters 24:885-8.

Hogg AG, Higham TF G, Dahm J. 1998. ${ }^{14} \mathrm{C}$ dating of modern marine and estuarine shellfish. Radiocarbon 40(2):975-84.

Heier-Nielsen S, Heinemeier J, Nielsen HL, Rud N. 1995. Recent reservoir ages for Danish fjords and marine waters. Radiocarbon 37(2):875-82.

Hideshima S, Matsumoto E, Abe O, Kitagawa H. 2001. Marine reservoir correction of northwest Pacific estimated from an annually banded coral of Ishigaki Island, Southern Japan. Radiocarbon. This issue.

Hughen KA, Overpeck JT, Lehman SJ, Kashgarian M, Southon J, Peterson LC, Alley R, Sigman DM. 1998. Deglacial changes in ocean circulation from an extended radiocarbon calibration. Nature 391:65-8.

Ingram BL, Southon JR. 1996. Reservoir ages in Eastern Pacific coastal and estuarine waters. Radiocarbon
38(3):573-82.

Lanting JN, van der Plicht J. 1998. Reservoir effects and apparent ${ }^{14} \mathrm{C}$-ages. Journal of Irish Archaeology 9: 151-65.

Kuzmin YV, Burr GS, Jull ATJ. 2001. ${ }^{14} \mathrm{C}$ reservoir correction ages in the Peter the Great Gulf, Sea of Japan, and eastern coast of the Kunashir, Southern Kuriles (Northwestern Pacific). Radiocarbon. This issue.

Monges Soares AM. 1993. The ${ }^{14} \mathrm{C}$ content of marine shells: evidence for variability in coastal upwelling off Portugal during the Holocene. In: Isotope techniques in the Study of Past and Current Environmental Changes in the Hydrosphere and Atmosphere (Proceedings) Vienna. p 471-485.

Olsson IU. 1996. ${ }^{14} \mathrm{C}$ dates and the reservoir effect. In: van der Plicht J, Punning J-M, editors. International Workshop on Isotope-Geochemical Research in the Baltic Region. Centre for Isotope Research Groningen. p 5-23.

Peck LS, Brey T. 1996. Bomb signals in old Antarctic brachiopods. Nature 380:207-8.

Sikes EL, Samson CR, Guilderson TP, Howard WR. 2000. Old radiocarbon ages in the southwest Pacific Ocean during the last glacial period and deglaciation. Nature 405:555-9.

Stuiver M, Braziunas TF. 1993. Modeling atmospheric ${ }^{14} \mathrm{C}$ influences and ${ }^{14} \mathrm{C}$ ages of marine samples to 10,000 BC. Radiocarbon 35(2):137-189.

Stuiver M, Pearson GW, Braziunas TF. 1986. Radiocarbon age calibration of marine samples back to 9000 cal yr BP. Radiocarbon 28(2B):980-1021.

Stuiver M, Polach HA. 1977. Discussion: reporting of ${ }^{14}$ C data. Radiocarbon 19(3):355-63.

Stuiver M, Reimer PJ, Braziunas TF. 1998. High-precision radiocarbon age calibration for terrestrial and marine samples. Radiocarbon 40(3):1127-51.

Wessel P, Smith WHF. 1998. New, improved version of the Generic Mapping Tools Released. EOS Transactions, AGU 79:579.

Yoneda M, Kitagawa H, van der Plicht J, Uchida M, Tanaka A, Uehiro T, Shibata Y, Morita M, Ohno T. 2000. Pre-bomb marine reservoir ages in the western north Pacific: Preliminary result on Kyoto University collection. Nuclear Instruments and Methods in Physics Research B172:377-81. 